\title{
Empirical Research on the Influence of Four Major Service Industries in Hong Kong on Its Economic Growth
}

\author{
Haiquan Tan \\ School of Economics, Jinan University, Guangzhou, China \\ Email: 784986424@qq.com
}

Received 19 March 2016; accepted 23 April 2016; published 26 April 2016

Copyright ( 2016 by author and Scientific Research Publishing Inc.

This work is licensed under the Creative Commons Attribution International License (CC BY). http://creativecommons.org/licenses/by/4.0/

(c) (i) Open Access

\begin{abstract}
Since service industry is the leading industry in Hong Kong; it contains four pillar industries including financial service, trade and logistics, tourism, and professional service and industrial as well as commercial support. Based on the regression analysis method, this article carried out empirical analysis on the relationship between four major service industries and economic growth in Hong Kong, by using the data of added value of four pillar industries and local total output from 1995 to 2014 in Hong Kong. The empirical results showed that financial service, trade and logistics, tourism, and professional service and industrial as well as commercial support drive economic growth positively, among which the positive effects of professional service and industrial as well as commercial support are the largest on economic growth. Meanwhile, the pairwise intersections of four supporting industries also facilitate economic growth with stable influencing index.
\end{abstract}

\section{Keywords}

Four Pillar Industries, Economic Growth, Regression Analysis

\section{Introduction}

\subsection{Background}

Hong Kong is a global center of finance, navigation and logistics, and trade with the reputation of "Shopping Paradise". Since financial service, trade and logistics, tourism, and professional service and industrial as well as commercial support are the pillar industries of Hong Kong, the total sum of their added value in 2014 occupied $56.12 \%{ }^{1}$, which played a vital role in Hong Kong economy. It is well known that these four major pillar indus-

${ }^{1}$ According to relevant calculation, the original data come from the website of Hong Kong census and statistics department. 
tries promote economic growth positively. However, what is their influence degree? Which industry affects Hong Kong economy largely? All these problems deserve our further research.

\subsection{Literature Review of Relationship between Service Industry and Economic Growth}

The founder of British classical economics Petty [1] implemented the researches related to the variation rule of tertiary industry with proposing, "Industrial earnings are larger than agricultural earnings while commercial earnings are larger than it”. Thus, labor force will flow into the department with higher earnings, which means that the proportion of industry and commerce will increase gradually. American economist Fuchs [2] raised "service economy" initially in the book of Service Economics, which, by taking the years from 1929 to 1965 as time axis, explored the difference of productivity variation between departments and further analyzed the influence of service economic growth on national economy based on the comparative analysis between service department and industrial sector as well as agricultural sector.

Domestic scholars also made many researches on the relationship between service industry and economic growth. By virtue of establishing the regression model based on the GDP and value-added document of tertiary industry during 1979-2008, Ye [3] concluded that there is bi-directional Granger causality existing between service industrial development and economic growth. According to the data obtained during 1992-1997, Wang [4] calculated the contributions of tertiary industry to Shanghai economic growth, which showed that the contribution rate of tertiary industry is obviously higher than that of secondary industry. By taking the 57 countries in low-income as well as middle-income groups in 1990, Huang [5] found that the added-value proportion of service industry and income level are not in a simple linear relation but that, with the increase of income level, the proportion of service industry changes from higher to lower than industrial proportion, which will increase sharply at last with becoming higher than industrial proportion again.

\subsection{Literature Review of Four Pillar Industries in Hong Kong Service Industry}

Domestic scholars also carried out some researches on these four pillar industries in Hong Kong. Based on the analysis of six financial centers by using the first-grade indicator of competence of international financial center, Lu [6] discovered that Hong Kong scored higher points in financial aggregation degree and financial internationalization while it is at middle level as for the aspect of financial scale. According to the relevant data during 1990-2007, Wang and Sun [7] analyzed the influence of seven major events on the two-way interaction of tourism. They found that before the return of Hong Kong, its economy was developed with higher tourism rate, which was in the powerful position in tourism interaction. However, after its return, the inbound tourism from mainland became the core of tourism interaction. Huang and Jiang [8] analyzed the China mainland as well as Hong Kong import and export data, which showed that there was no co-integration relationship between the indexes of China mainland and Hong Kong while the import and export of Hong Kong are in co-integration relationship and causality. Xiao [9] proposed that the competitive advantages of Hong Kong navigation has been weakened gradually, so the only outlet is to develop high-end navigation service center. Apart from the individual analysis of four pillar industries, some scholars carried out comparative analysis on them. Chen [10] discovered that the contribution rate of influence of tourism on economic growth has been on rise since 2004 while the influence of trade as well as logistics has been in descending. Xie [11] found that the four pillar industries in Hong Kong have strong attraction to labor forces, among which the driving effect of tourism is the largest, followed by professional service and industrial as well as commercial support and financial service, trade and logistics industry are in the end.

To sum up, it is obvious that only a few scholars research on the relationship between four pillar industries and economic growth; meanwhile, the articles about its empirical analysis are few. Since the four pillar industries is the vitality of Hong Kong economy, this article explored the relationship between Hong Kong service industry and economic growth.

\section{Development Status of Four Pillar Industries in Hong Kong Service Industry}

\subsection{Status of Four Pillar Industries in Hong Kong Service Industry}

The GDP in Hong Kong in 2014 was 2.26 trillion HKD where the added value of four pillar industries including 
financial service, trade and logistics, tourism, and professional service and industrial as well as commercial support was 1.27 trillion $\mathrm{HKD}^{2}$, which accounted for $56.12 \%$ of GDP. Therefore, the status of four pillar industries is decisive in Hong Kong. As shown in Figure 1, the four pillar industries in Hong Kong presents upward tendency together with GDP while their gains and influence of four pillar industries on economic growth were all different slightly. The average growth rate of four pillar industries from 2009 to 2014 were 7.41\%, 6.42\%, $17.14 \%$ and $6.28 \%$ separately, and the average growth rate of GDP at the same term was 6.36\%. The acceleration of financial service, tourism, and professional service and industrial as well as commercial support was higher than that of GDP, but the acceleration of trade and logistics was lower than that of GDP.

\subsection{Development Status of Hong Kong Financial Industry}

The added value of financial service industry in 2014 was 365.9 billion HKD, among which the added value of banking service was 229.1 billion HKD, insurance service was 67 billion HKD and other financial service was 69.8 billion HKD with occupying 62.61\%, 18.31\% and 19.08\% separately. The total employment of financial service was 236,500, which contained $42.15 \%$ in banking service, $21.73 \%$ in insurance service and $36.11 \%$ in other financial service. These data suggested that the financial service in Hong Kong is in the development mode that banking service domains while insurance service and other financial services are in coexistence.

\subsection{Development Status of Hong Kong Trade and Logistics}

The total value of purchased commodities in Hong Kong import and export trade for sales in 2014 was 3.36 trillion HKD, where the total surplus value reached to 314.64 billion HKD and quantity of employment was up to 492,146. With the further signing of CEPA supplementary agreement and WTO trade facilitation agreement, Hong Kong import and export trade ushered new historical opportunity, which will promote more vigorous development.

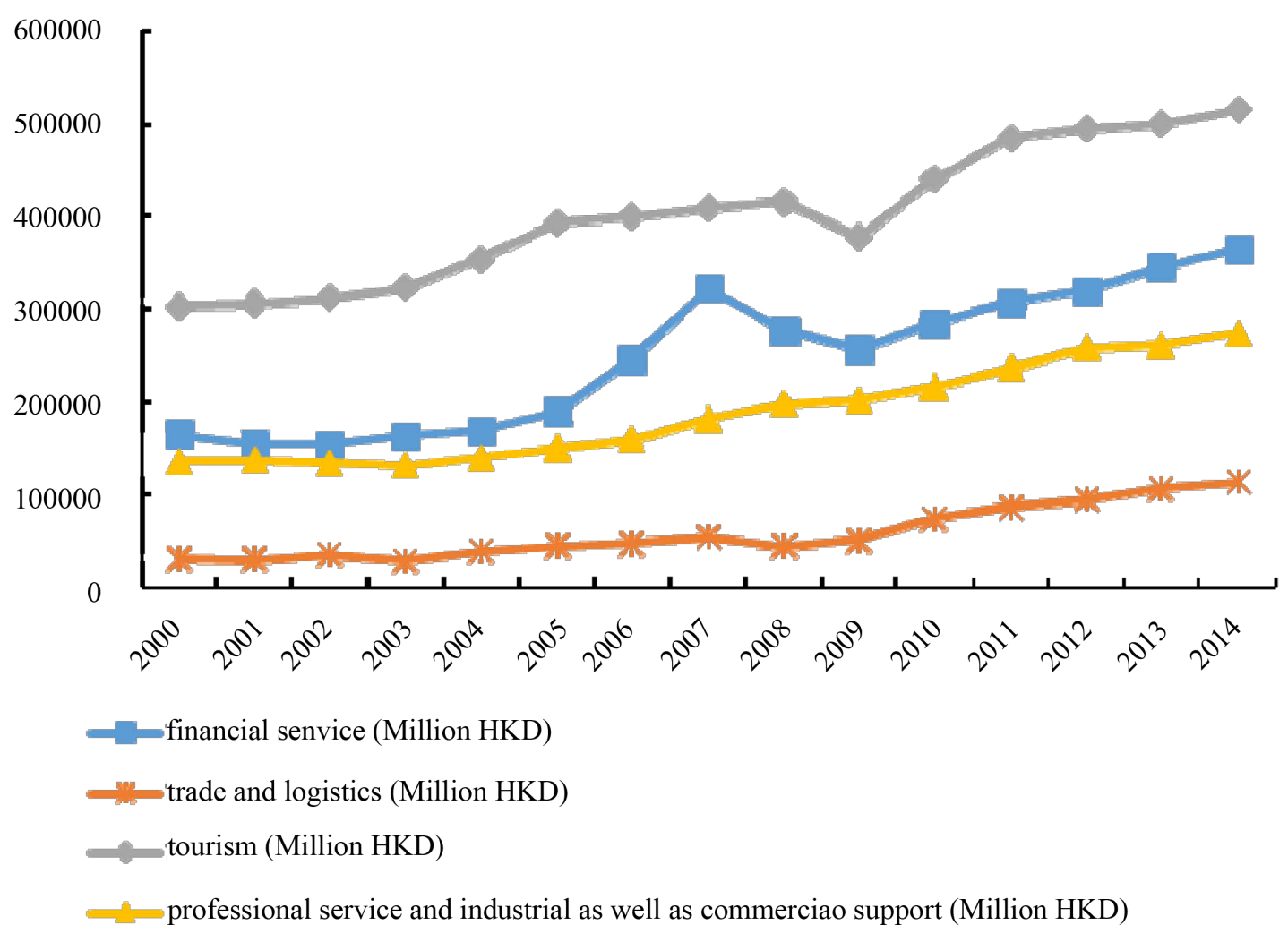

Figure 1. The added value of GDP in Hong Kong and four pillar industries from 2000 to 2014.

\footnotetext{
${ }^{2}$ The data come from Hong Kong Census and Statistics Department. The added value in this article is amount to the industrial year's output.
} 
Logistics in Hong Kong faces a lot of challenges. In 2005, the container throughputs of Singapore port replace that of Hong Kong port, which became the first in the world. By 2014, Hong Kong had fallen to the fourth, while the top three in the world is Shanghai, Singapore, Shenzhen. With the development of Chinese mainland ports, the share of Hong Kong is shrinking. Therefore, the position of international shipping center in is being challenged.

\subsection{Development Status of Hong Kong Tourism}

After 2003, for the sake of stimulating the development of tourism, Hong Kong gradually opened independent travel for mainland citizens. By the end of 2014, the number of mainland tourists visiting Hong Kong reached to 47.25 million, which increased by 4.58 times compared with 2003 with accounting for $77.66 \%$ of the total amount of tourists visiting Hong Kong. Meanwhile, the consumption amount of overnight mainland tourists achieved 166.03 billion HKD with occupying $75.11 \%$ of the total amount. The purchasing power of mainland tourists is increasing with the economic development of mainland China, which will promote the prosperity of Hong Kong tourism.

\subsection{Development Status of Hong Kong Professional Service and Industrial as Well as Commercial Support}

Since the professional service industry in Hong Kong is knowledge-intensive industry, it has the characteristics of depending on specialized knowledge and offer intermediary service to other industries. The manufacturing industry in Hong Kong is not developed with smaller demands for professional service. Due to the backward professional service of Mainland China, the signing of CEPA created opportunity for the introduction of Hong Kong professional service to mainland. The added value of Hong Kong professional service was 273.2 billion HKD in 2014, which accounted for $21.56 \%$ of the total added value of four pillar industries with $5.00 \%$ of year-on-year growth. Moreover, its scale was tiny compared with other three pillar industries, because of the smaller Hong Kong market and weaker execution force of CEPA.

In short, during these ten years' development, the four pillar industries are all facing opportunities and challenges. In order to deeply understand the relationship between the structure of service industry in Hong Kong and economic growth, we think the quantitative analysis of the influence of four pillar industries on economic growth is necessary.

\section{Empirical Analysis of Four Pillar Industrial Development and Economic Growth in Hong Kong}

\subsection{Variable Selection and Data Processing}

In order to research the influence of four pillar industries on Hong Kong economic growth, this article carried out regression analysis by selecting the added value of four pillar industries and Hong Kong local gross domestic product during 1995-2004 ${ }^{3}$. Financial service, trade and logistics, tourism, and professional service and industrial as well as commercial support are represented by FC, TD, TR and PS separately. The control variables are added to increase stability. The number of patents (PT) qualified in Hong Kong stands for the technical progress of Hong Kong since its improvement will promote the enhancement of social efficiency and then economic growth. The gross fixed capital formation of Hong Kong (K) represents local capital stock, which means higher fixed assets investment will drive economic growth. The number of labor force in Hong Kong (L) indicates local human capital, which means the more the labor force factors, the greater promotion force to economy will be. All these three indexes are the control variables in traditional meaning. The index variable of amount was in logarithmic treatment to reduce heteroscedasticity, which is shown in Table 1 and Table 2.

\subsection{Data Sources}

The data of the added value of four pillar industries including financial service, trade and logistics, tourism, and professional service and industrial as well as commercial support, local gross domestic product, gross fixed capital

\footnotetext{
${ }^{3}$ The data of four pillar industries in 1999 was lost and the data of professional service as well as industrial and commercial support are lost
} too. 
Table 1. Variable index.

\begin{tabular}{|c|c|c|c|}
\hline Variable Name & Variable Definition & Remark & Type \\
\hline GDP & $\begin{array}{c}\text { Annual Gross Domestic Product in } \\
\text { Hong Kong (Million HKD) }\end{array}$ & Take the Logarithm & Explained Variable \\
\hline $\mathrm{FC}$ & $\begin{array}{l}\text { Annual Added Value of Financial } \\
\text { Service (Million HKD) }\end{array}$ & Take the Logarithm & Explaining Variable \\
\hline TD & $\begin{array}{l}\text { Annual Added Value of Trade and } \\
\text { Logistics (Million HKD) }\end{array}$ & Take the Logarithm & Explaining Variable \\
\hline TR & $\begin{array}{l}\text { Annual Added Value of Tourism } \\
\text { (Million HKD) }\end{array}$ & Take the Logarithm & Explaining Variable \\
\hline PS & $\begin{array}{l}\text { Annual Added Value of Professional Service } \\
\text { and Industrial and Commercial Support } \\
\text { (Million HKD) }\end{array}$ & Take the Logarithm & Explaining Variable \\
\hline K & $\begin{array}{l}\text { Fixed Capital Formation of Local Hong Kong } \\
\text { (Million HKD) }\end{array}$ & Take the Logarithm & Control Variable \\
\hline $\mathrm{L}$ & $\begin{array}{c}\text { Annual Number of Labor Force in } \\
\text { Hong Kong (Person) }\end{array}$ & Take the Logarithm & Control Variable \\
\hline PT & $\begin{array}{l}\text { Number of Patents Approved in } \\
\text { Hong Kong (Item) }\end{array}$ & Take the Logarithm & Control Variable \\
\hline
\end{tabular}

Table 2. Statistical description of each variable.

\begin{tabular}{|c|c|c|c|c|}
\hline Variable Name & Mean Value & Standard Deviation & Minimum Value & Maximum Value \\
\hline GDP & $1,546,402$ & $332,253.9$ & $1,119,006$ & $2,258,225$ \\
\hline FC & $221,110.5$ & $85,809.31$ & 110,500 & 365,900 \\
\hline TD & $373,652.6$ & $86,131.77$ & 250,300 & 515,700 \\
\hline TR & $53,089.47$ & $27,601.99$ & 25,200 & 112,500 \\
\hline PS & $180,444.4$ & 49,203 & 130,800 & 273,200 \\
\hline $\mathrm{K}$ & $376,564.1$ & $78,601.2$ & 272,127 & 530,997 \\
\hline $\mathrm{L}$ & $3,506,265$ & $231,223.1$ & $3,000,700$ & $3,876,400$ \\
\hline PT & 4224.95 & 1909.037 & 1417 & 7102 \\
\hline
\end{tabular}

formation, number of labor force, and quantity of patents qualified in Hong Kong come from the website of Hong Kong Census and Statistics Department.

\subsection{Modeling}

The regression model is established as follows:

$$
Y_{t}=\theta+\alpha_{0} X_{t}+\sum_{i=1}^{n} a_{i} Z_{i t}+v_{t}
$$

The Equation (1) is used for researching the influence of added value in four pillar industries on economic growth, where the explained variable is LnGDP; $X_{t}$ means the explaining variable, which are LnFC, LnTD, LnTR and LnPS respectively. $Z_{i t}$ represents the added control variable. The coefficient value this article concerned is $\alpha_{0}$, which indicates the effect elasticity of the added value in four pillar industries on GDP.

$$
Y_{t}=\delta+\beta_{0} X_{t} \times X_{t}^{\prime}+\sum_{i=1}^{n} \beta_{i} Z_{i t}+e_{t}
$$

The Equation (2) is used for researching the common influence of interaction of four pillar industries on eco- 
nomic growth, which is processed by cross terms. The explained variable in it is LnGDP; $X_{t}$ means the explaining variable, which are LnFC, LnTD, LnTR and LnPS respectively. Meanwhile, $X^{\prime}$ also can be used as the explaining variable of four pillar industries, which are LnFC, LnTD, LnTR and LnPS separately with guaranteeing that $X_{t}$ and $X_{t}^{\prime}$ will not appear the same variable simultaneously. $\beta_{i}$ indicates the index of control variable, and $Z_{i t}$ means the added control variable. The coefficient value this article concerned here is $\beta_{0}$, which indicates the effect index of cross terms on GDP.

\subsection{Demonstration Result}

Firstly, the equation $Y_{t}=\theta+\alpha_{0} X_{t}+\sum_{i=1}^{n} a_{i} Z_{i t}+v_{t}$ (1) is used to analyze the influence of added value of four pillar industries on economic growth independently. Add the appropriate control variable $\mathrm{LnK}$, $\mathrm{LnL}$ and LnPT.

The regression results of the (1), (3), (5) and (7) in Table 3 showed that the simultaneous effect of FC, TD, TR and PS on GDP is positive from 1995 to 2014. Meanwhile, after adding control variables, the adj. $R^{2}$ of (2), (4), (6) and (8) increases gradually with keeping the coefficient positive. According to the value of $\alpha_{0}$ in each regression, every $1 \%$ increases of FC, TD, TR and PS can drive $0.07 \%, 0.38 \%, 0.12 \%$ and $0.40 \%$ growths of GDP respectively, which indicate that the positive influence of professional service and industrial as well as commercial support is the largest.

The common influence of interaction of four pillar industries on Hong Kong GDP was discussed next. Put LnFC*LnTD, LnFC*LnTR, LnFC*LnPS, LnTD*LnTR, LnTD*LnPS and LnTR*LnPS into Equation (2) $Y_{t}=\delta+\beta_{0} X_{t} \times X_{t}^{\prime}+\sum_{i=1}^{n} \beta_{i} \mathrm{Z}_{i t}+e_{t}$ as explaining variables. LnGDP is used as explained variable. The control variables are $\mathrm{LnK}, \mathrm{LnL}$ and $\mathrm{LnPT}$. Then, the result is shown in Table 4.

According to Table 4, it can be seen that the coefficient of the explaining variables in regression Equations (1), (3), (5), (7), (9) and (11) is positive, which means the mutual interaction of four pillar industries promotes

Table 3. The respective influence of four pillar industries on GDP.

\begin{tabular}{|c|c|c|c|c|c|c|c|c|}
\hline & (1) & (2) & (3) & (4) & (5) & (6) & (7) & (8) \\
\hline & LnGDP & LnGDP & LnGDP & LnGDP & LnGDP & LnGDP & LnGDP & LnGDP \\
\hline \multirow[t]{2}{*}{ LnFC } & $0.39^{* * * *}$ & $0.07^{* *}$ & & & & & & \\
\hline & $(0.08)$ & $(0.03)$ & & & & & & \\
\hline \multirow[t]{2}{*}{ LnTD } & & & $0.83^{* * * *}$ & $0.38^{* * * *}$ & & & & \\
\hline & & & $(0.08)$ & $(0.11)$ & & & & \\
\hline \multirow[t]{2}{*}{ LnTR } & & & & & $0.41^{* * *}$ & $0.12^{* * *}$ & & \\
\hline & & & & & $(0.04)$ & $(0.04)$ & & \\
\hline \multirow[t]{2}{*}{ LnPS } & & & & & & & $0.78^{* * *}$ & $0.40^{* * *}$ \\
\hline & & & & & & & $(0.05)$ & $(0.05)$ \\
\hline \multirow[t]{2}{*}{ LnK } & & $0.45^{* * *}$ & & $0.39^{* * * *}$ & & $0.33^{* * * *}$ & & $0.16^{* * *}$ \\
\hline & & $(0.04)$ & & $(0.04)$ & & $(0.06)$ & & $(0.05)$ \\
\hline \multirow[t]{2}{*}{ LnL } & & $1.88^{* * *}$ & & $1.03^{* *}$ & & $1.67^{* * *}$ & & $1.40^{* * *}$ \\
\hline & & $(0.19)$ & & $(0.37)$ & & $(0.21)$ & & $(0.12)$ \\
\hline \multirow[t]{2}{*}{ cons } & $9.41^{* * *}$ & $-20.61^{* * *}$ & $3.63^{* * *}$ & $-11.12^{* *}$ & $9.79^{* * *}$ & $-16.46^{* * *}$ & $4.80^{* * *}$ & $-13.67^{* * *}$ \\
\hline & $(0.98)$ & $(2.47)$ & $(0.97)$ & $(4.37)$ & $(0.40)$ & (3.16) & $(0.64)$ & $(1.66)$ \\
\hline$N$ & 19 & 19 & 19 & 19 & 19 & 19 & 18 & 18 \\
\hline $\operatorname{adj} . R^{2}$ & 0.564 & 0.973 & 0.868 & 0.976 & 0.873 & 0.975 & 0.927 & 0.993 \\
\hline
\end{tabular}

Standard errors in parentheses. ${ }^{*} p<0.10,{ }^{* *} p<0.05,{ }^{* * *} p<0.01$. 
Table 4. Common influence of interaction of four pillar industries on GDP.

\begin{tabular}{|c|c|c|c|c|c|c|}
\hline & (1) & (2) & (3) & (4) & (5) & (6) \\
\hline & LnGDP & LnGDP & LnGDP & LnGDP & LnGDP & LnGDP \\
\hline \multirow[t]{2}{*}{ LnFC*LnTD } & $0.03^{* * *}$ & $0.01^{* * *}$ & & & & \\
\hline & $(0.00)$ & $(0.00)$ & & & & \\
\hline \multirow[t]{2}{*}{ LnFC*LnTR } & & & $0.02^{* * * *}$ & $0.01^{* * * *}$ & & \\
\hline & & & $(0.00)$ & $(0.00)$ & & \\
\hline \multirow[t]{2}{*}{ LnFC*LnPS } & & & & & $0.03^{* * *}$ & $0.01^{* * *}$ \\
\hline & & & & & $(0.00)$ & $(0.00)$ \\
\hline \multirow[t]{2}{*}{ LnK } & & $0.40^{* * * *}$ & & $0.33^{* * * *}$ & & $0.32^{* * * *}$ \\
\hline & & $(0.02)$ & & $(0.05)$ & & $(0.02)$ \\
\hline \multirow[t]{2}{*}{ LnL } & & $0.75^{* * *}$ & & $1.21^{* * *}$ & & $0.93^{* * *}$ \\
\hline & & (0.19) & & $(0.23)$ & & $(0.13)$ \\
\hline \multirow[t]{2}{*}{ LnPT } & & 0.02 & & 0.01 & & $0.04^{* *}$ \\
\hline & & $(0.02)$ & & $(0.03)$ & & $(0.02)$ \\
\hline \multirow[t]{2}{*}{ _cons } & $10.26^{* * *}$ & -4.35 & $11.46^{* * *}$ & $-9.44^{* *}$ & $10.15^{* * *}$ & $-5.97^{* * *}$ \\
\hline & $(0.37)$ & $(2.60)$ & $(0.19)$ & (3.29) & $(0.24)$ & (1.79) \\
\hline$N$ & 18 & 18 & 18 & 18 & 17 & 17 \\
\hline \multirow[t]{3}{*}{$\operatorname{adj} . R^{2}$} & 0.874 & 0.994 & 0.930 & 0.987 & 0.948 & 0.997 \\
\hline & (7) & (8) & (9) & (10) & (11) & (12) \\
\hline & LnGDP & LnGDP & LnGDP & LnGDP & LnGDP & LnGDP \\
\hline \multirow[t]{2}{*}{ LnTD*LnTR } & $0.02^{* * *}$ & $0.01^{*}$ & & & & \\
\hline & $(0.00)$ & $(0.00)$ & & & & \\
\hline \multirow[t]{2}{*}{ LnTD*LnPS } & & & $0.04^{* * * *}$ & $0.02^{* * *}$ & & \\
\hline & & & $(0.00)$ & $(0.00)$ & & \\
\hline \multirow[t]{2}{*}{ LnTR*LnPS } & & & & & $0.02^{* * * *}$ & $0.01^{* *}$ \\
\hline & & & & & $(0.00)$ & $(0.00)$ \\
\hline \multirow[t]{2}{*}{ LnK } & & $0.37^{* * *}$ & & $0.22^{* * *}$ & & $0.28^{* * *}$ \\
\hline & & $(0.07)$ & & $(0.04)$ & & $(0.08)$ \\
\hline \multirow[t]{2}{*}{ LnL } & & $1.45^{* * *}$ & & $0.94^{* * * *}$ & & $1.47^{* * * *}$ \\
\hline & & $(0.25)$ & & $(0.18)$ & & $(0.21)$ \\
\hline \multirow[t]{2}{*}{ LnPT } & & 0.02 & & & & 0.01 \\
\hline & & $(0.03)$ & & & & $(0.03)$ \\
\hline \multirow[t]{2}{*}{ _cons } & $11.00^{* * *}$ & $-13.41^{* * * *}$ & $8.82^{* * * *}$ & $-5.91^{* *}$ & $11.15^{* * * *}$ & $-12.77^{* * *}$ \\
\hline & $(0.24)$ & (3.80) & $(0.21)$ & (2.74) & $(0.23)$ & (3.27) \\
\hline $\mathrm{N}$ & 19 & 19 & 18 & 18 & 18 & 18 \\
\hline $\operatorname{adj} . R^{2}$ & 0.909 & 0.976 & 0.975 & 0.991 & 0.914 & 0.980 \\
\hline
\end{tabular}

Standard errors in parentheses. ${ }^{*} p<0.10,{ }^{* *} p<0.05,{ }^{* * *} p<0.01$.

Hong Kong economic development positively. In order to further verify this conclusion, the tentative addition of control variables in Equations (2), (4), (6), (8), (10) and (12) was made with continuous better matching result and stable coefficient. It showed that the influence of the cross terms of four pillar industries on GDP are all 
maintained between 0.01 and 0.04 , which reflected that the positive effect of mutual interaction of four pillar industries on GDP is stable.

\section{Conclusions}

This article analyzed the relationship between the four major service industries in Hong Kong and economic growth based on the establishment of regression model. The research showed that financial service, trade and logistics, tourism, and professional service and industrial as well as commercial support all affect Hong Kong economy positively in different degrees. The specific conclusion is as follows:

1) By establishing regression model through the added value of financial service, trade and logistics, tourism, and professional service and industrial as well as commercial support and the GDP in Hong Kong during 1995-2014, it can be known that the four pillar industries promote economic growth positively where the influence factors of professional service and industrial as well as commercial support are the highest. Every $1 \%$ increase of professional service and industrial as well as commercial support generates $0.40 \%$ increase of the GDP in Hong Kong, which is followed by trade and logistics since every $1 \%$ increase of its added value will lead to 0.38\% increase of the GDP in Hong Kong. In addition, the influence coefficient of financial service and tourism is smaller on Hong Kong economy, which indicates that their promotion of Hong Kong economy is weaker because every $1 \%$ increase of financial service and tourism will only stimulate $0.07 \%$ and $0.12 \%$ increase of the GDP in Hong Kong.

2) We established the regression model of each pairwise intersection of financial service, trade and logistics, tourism, and professional service and industrial as well as commercial support, and the GDP in Hong Kong. Finally, the research found that the common interaction of four pillar industries can all promote Hong Kong economic growth with small difference of impact factor.

\section{References}

[1] Petty, W. (1978) Political Arithmetic. Commercial Press, Beijing.

[2] Fuchs, R.V. (1987) Service Economics. Commercial Press, Beijing.

[3] Ye, A.H. (2010) Empirical Research on Relationship between Chinese Service Industrial Development and Economic Growth. Statistics and Decision, 22, 117-119.

[4] Wang, X.J. (2009)Research on Characteristics of Shanghai Service Industrial Development and Its Relationship with Economic Growth . Study of Shanghai Economy, 5, 79-85.

[5] Huang, S.J. (2000) Service Industry and Economic Growth. Economic Science Press, Beijing.

[6] Lu, H.J. (2007) Evaluation Research on the Competitiveness of International Financial Center. Study of Finance and Economics, 3, 47-56.

[7] Wang, J.J. and Sun, G.N. (2010) Relationship between Mainland China and Hong Kong during the Past 20 Years and Analysis of Influence of Major Event on Both Shores’ Tourism interaction . Economic Geography, 2, 317-323.

[8] Huang, Q.B. and Jiang, L. (2008) Empirical Research on Relationship between China Mainland and Hong Kong Trade. International Economics and Trade Research, 10, 33-37.

[9] Xiao, Z.X. (2007) Hong Kong Shall Develop into High-End Navigation Service Center. Water Transport Management, 7, 5-9.

[10] Chen, C.X. (2013) Empirical Research on Relationship between Hong Kong Industrial Structural Evolution and Economic Growth—Based on Four Pillar Industries. Contemporary Hong Kong and Macao Studies, 2, 35-45+128.

[11] Xie, B.J. (2013) Influence of Hong Kong Four Pillar Industrial Structures on Employment Structure and Development Analysis. Journal of Jinan University (Philosophy and Social Sciences), 7, 39-46. 